\title{
Genetic Divergence in the Poecilia sphenops Complex in Middle America
}

\author{
BETTY LOU HILTON BRETT and BRUCE J. TURNER \\ The University of Rochester, Rochester, NY 14627, USA; \\ Virginia Polytechnical Institute, Blacksburg, VA 24061, USA; \\ The University of Michigan, Museum of Zoology, Ann Arbor, MI 48109, USA
}

Key Word Index - Poecilia; Poecilidae; Pisces; isozymes; starch gel electrophoresis; allozymes; chemosystematics.

Abstract - Based on morphological and allozymic evidence, the Poecilia sphenops complex is an array of at least ten biological species ranging from Mexico to Venezuela (systematics are unclear south of Mexico) and not a single polytypic species as some authors have previously suggested. The allozyme data also suggest that the populations of mollies with tricuspid teeth on the Atlantic and Pacific coasts of Mexico now referred to as $P$. sphenops (sensu stricto/ may represent at least two biological species. As some of the members of the complex are used as general research animals, experimental biologists should ascertain the specific identity of their stocks.

\section{Introduction}

The shortfin mollies of the Poecilia sphenops complex are ubiquitous in fresh and brackish waters of Mexico, Middle America, northern South America and adjacent islands. The morphology of the components of this complex is often superficially similar. This similarity, coupled with the sometimes marked differentiation of some populations, has led to considerable taxonomic confusion, exemplified by two contending views of the systematics of the group. One view, tentatively advanced by Rosen and Bailey [1] and widely held among European biologists (e.g. Zeiske [2]; Parzefall [3-5]) envisions a single, highly variable polytypic species, $P$. sphenops, ranging from the Rio Grande drainage in north-eastern Mexico to coastal Venezuela. The second view (Schultz and Miller [6]; Miller [7, 8]; Bussing [9]) holds that the complex is an assemblage of nine or more biological species with partially overlapping ranges (Table 1 ). If the second view is correct, the complex would represent one of the major radiations of poeciliid fishes in North and Middle America.

Some of the members of the complex are used widely as experimental animals [2-5, 10-20]. Hence, resolution of this issue is especially

(Received 2 June 1982) important. For example, the cave molly used by Parzefall [15], Peters et al. [17] and Zeiske [2] has unicuspid inner teeth. Conclusions about the cave mollies were based on comparisons with surface mollies. However, it is difficult to determine if the surface forms were the unicuspid $P$. mexicana or the tricuspid $P$. sphenops. Erroneous conclusions could be drawn about the behaviour and physiology of cave mollies if $P$. sphenops was used as the surface form instead of $P$. mexicana.

In this paper we present the first substantial non-morphological evidence that many of the components of the complex are genetically distinct, thus arguing against a polytypic interpretation of this complex.

\section{Results}

Fourteen loci showed no detectable variation in any of the populations surveyed: Adh (alchohol dehydrogenase), Ldh-1 (lactate dehydrogenase1), Ldh-3, Prv-1 (parvalbumin-1), Prv-2, Prv-3, Fum (fumarate-hydratase), Gpd (glyceraldehyde3-phosphate dehydrogenase), Idh-1 (isocitrate dehydrogenase-1), Cpk-2 (creatine kinase-2), Cpk-1, Ak-1 (adenylate kinase-1), Aco- 1 (aconitate hydratase-1), Gpi-2 (glucosephosphate isomerase). Fifteen other loci showed electrophoretic variation (Table 2): Aco-2, Agp (alpha-glycerol 
TABLE 1. DISTRIBUTION OF MORPHOLOGICAL FORMS IN POECILIA SUBGENUS MOLLIENESIA

\begin{tabular}{|c|c|c|c|}
\hline Taxa & Range & Collection sites ${ }^{*}$ & Comments \\
\hline P. butleri Jordan 1889 & $\begin{array}{l}\text { Pacific coast, Rio Fuerte, Mexico. } \\
\text { S. to W. Guatemala }\end{array}$ & M66-18 near Tepic, Nayarit & $\begin{array}{l}\text { Unicuspid teeth; M66-18 is N. of } \\
P \text {. sphenops range }\end{array}$ \\
\hline P. catemaconis Miller 1975 & $\begin{array}{l}\text { Laguna Catemaco, Veracruz. } \\
\text { Mexico }\end{array}$ & Not available & $\begin{array}{l}\text { Tricuspid teeth; endemic to } \\
\text { Laguna Catemaco, only Poecilia } \\
\text { in the lake }\end{array}$ \\
\hline P. chica Miller 1975 & $\begin{array}{l}\text { Rio Purificación, and adjacent } \\
\text { streams, Jalisco, Mexico }\end{array}$ & M66-14 Rio Apamila, Jalisco & $\begin{array}{l}\text { Tricuspid teeth; endemic to } \\
\text { R. Purificación and vicinity }\end{array}$ \\
\hline P. "gracilis" † (cf. Regan 1913) & Lago de Petén, Guatemala & $\begin{array}{l}\text { M71-29 Arroyo lxiu, Trib. Lago } \\
\text { de Petén }\end{array}$ & $\begin{array}{l}\text { Unicuspid teeth; taxonomic } \\
\text { status unclear at this time, } \\
\text { perhaps a lacustrine derivative of } \\
\text { P. mexicana (Fig. } 2 \mathrm{E} \text { and } 2 \mathrm{~F} \text { ); } \\
\text { analysis based on offspring of } \\
\text { one female }\end{array}$ \\
\hline P. latipunctata Meek 1904 & Rio Tamesi. Tamaulipas, Mexico & Not available & $\begin{array}{l}\text { Endemic to R. Tamesi, unicuspid } \\
\text { teeth }\end{array}$ \\
\hline \multirow[t]{3}{*}{ P. mexicana Steindachner 1863} & $\begin{array}{l}\text { Rio San Juan, Mexico, at least } \\
\text { to Lago Izabal, Guatemala }\end{array}$ & $\begin{array}{l}\text { M68.29 P. mexicana Veracruz, } \\
\text { Mexico } \\
\text {-M77.39 P. m. limantouri } \\
\text { Monterrey, Mexico } \\
\text { M77.38 P. mexicana Corozal, } \\
\text { Belize }\end{array}$ & Unicuspid teeth \\
\hline & & $\begin{array}{l}\text {-M77-41 P. mexicana Siquirres, } \\
\text { Costa Rica }\end{array}$ & Originally identified as $P$. gilli \\
\hline & & $\begin{array}{l}\text { - M77-42 P. mexicane Pensharst, } \\
\text { Costa Rica }\end{array}$ & Originally identified as $P$. gilli \\
\hline P. orri Fowler 1943 & $\begin{array}{l}\text { Costal Yucatan Peninsula } \\
\text { (Quintana Roo) S. and E. }\end{array}$ & M72-1 Belize River mouth, Belize & $\begin{array}{l}\text { Unicuspid teeth; M72-1 is } \\
\text { sympatric with } P \text {. mexicana }\end{array}$ \\
\hline \multirow[t]{2}{*}{ P. sphenops Valenciennes 1846} & $\begin{array}{l}\text { Just N. of Veracruz to Río } \\
\text { Coatzacoalcos, Mexico }\end{array}$ & $\begin{array}{l}\text { M67.2 } 35 \mathrm{~km} \text { S. of Veracruz } \\
\text { L68-7 Laguna Isleta, W. of } \\
\text { Minatitlan, Veracruz }\end{array}$ & $\begin{array}{l}\text { Tricuspid teeth (Fig. } 2 \mathrm{~B} \text { ); M67-2 } \\
\text { Atlantic slope form is sympatric } \\
\text { with } P \text {. mexicana }\end{array}$ \\
\hline & $\begin{array}{l}\text { Pacific slope of Mexico and } \\
\text { W. Guatemala }\end{array}$ & $\begin{array}{l}\text { M76-20 Rio Marques-Rio Balsas } \\
\text { near Nuevo Italia Michoacán }\end{array}$ & $\begin{array}{l}\text { Tricuspid teeth; Pacific slope or } \\
\text { R. Balsas form, sympatric with } \\
\text { P. butleri }\end{array}$ \\
\hline P. sulphuraria Alvarez 1948 & W. of Teapa, Tabasco, Mexico & Not available & $\begin{array}{l}\text { Unicuspid teeth; inhabits sulphur } \\
\text { springs, bright yellow fins }\end{array}$ \\
\hline $\begin{array}{l}\text { P. vandepolli van Lidth de Juede } \\
1887\end{array}$ & $\begin{array}{l}\text { Coastal Venezuela and the } \\
\text { Netherlands Antilles }\end{array}$ & - M76-48 Curaçao & Unicuspid teeth (Fig. 2C and 2D) \\
\hline
\end{tabular}

* Indicates field samples; no circle indicates samples from laboratory stocks; the first figure given for each collection station is the year of collection.

†The taxonomic status of Poecilia gracilis Regan (proposed as a replacement name for $P$. petenensis Gunther) is not clear, the name is preoccupied by Poecilia gracilis Valenciennes, a synonym of Cniesterodon decemmaculatus (see [1], p. 77 ). Regan's fish is therefore referred to as Poecilia "gracilis".

phosphate dehydrogenase), Cpk-3, Es-5 (esterase5), Got-1 (glutamate oxaloacetate transferase-1), Got-2, Mdh-1 (malate dehydrogenase-1), Mdh-2, Mdh-3, Gpi-1, Sod (superoxide dismutase), 6Pgd (6-phosphoglucose dehydrogenase), Pgm-1 (phosphoglucomutase-1), Cpk-1, Xdh (xanthine dehydrogenase), and Ldh-2. Hemoglobins were not surveyed extensively, but there appeared to be three non-polymorphic hemoglobin loci in the few species examined. The resolution of $/ d h-2$, Es-4, Got-3, Ada (adenosine deaminase) and A/d (aldolase) was poor and these loci were not included in the analysis. In all $\mathbf{2 9}$ loci were used in the analyses.

Although a small sample size was used, we feel that eight fish adequately represent any laboratory 


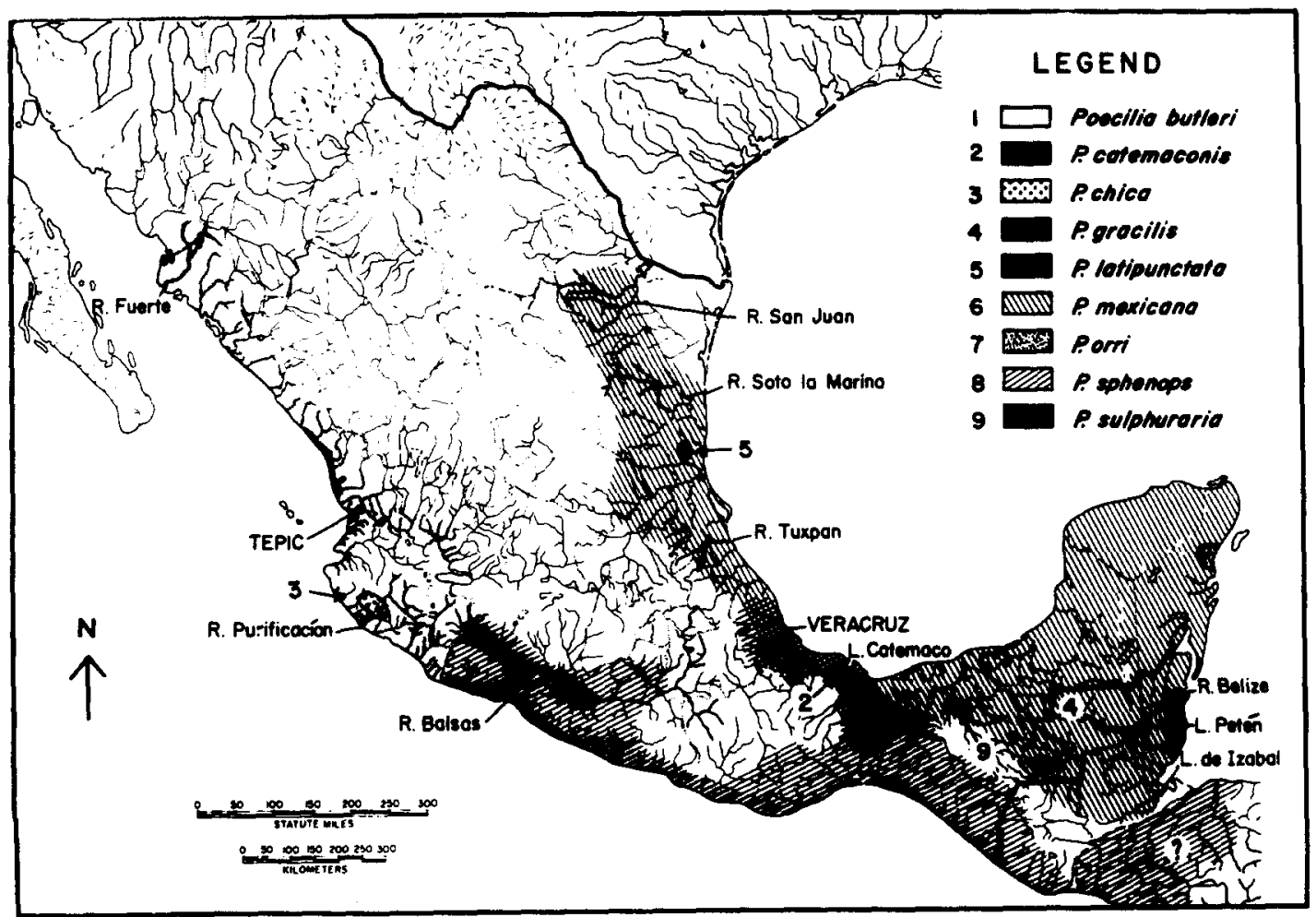

FIG. 1. DISTRIBUTIONS OF POECILIA IN MEXICO AND NORTHERN CENTRAL AMERICA.

stock. Although only 16 genomes represented a species, 29 loci were used. Nei [21] has shown that a large number of loci and a few individuals give a smaller variance between populations than a large sample size and a few loci. The laboratory stocks most probably adequately represent the field populations from which they came because: (a) the major alleles of laboratory stocks of the three most widespread species, $P$. mexicana, $P$. sphenops, (Atlantic) and $P$. butleri, are the same as those found at many locations in the wild [22]; (b) the alleles in the laboratory are still segregating (i.e. there are polymorphisms); (c) field studies of the most widespread species confirm intraspecific Nei similarity values of $0.94-0.99$ [22]. $P$. chica, $P$. vandepolli, $P$. orri and $P$. "gracilis" occur over a much smaller geographical area (Fig. 1) and the allozymic variation in these fish is not expected to vary as much as in widespread species. The interspecific values $(0.65-0.83)$ fall greatly below the intraspecific values, with $P$. mexicana vs $P$. "gracilis" being the only exception if one considers the Balsas $P$. sphenops to be specifically distinct. Based on this evidence, we conclude that $P$. mexicana, $P$. sphenops, $P$. butleri, $P$. chica, $P$. orri and $P$. vandepolli represent valid taxa at the specific level. The status of $P$. "gracilis", $P$. gilliand the Balsas form of $P$. sphenops remain in question as do several species which were not examined in this study ( $P$. catamaconis Miller, 1975; $P$. latipunctata, both of which occur in restricted ranges on the Atlantic coast of Mexicol. P. latipinna is the only sailfin molly that has been examined electrophoretically [23]. $P$. velifera Regan and $P$. petenensis Gunther, the other two sailfins, have yet to be examined. Nei similarity values (/) between $P$. mexicana laboratory stocks collected in 1968 and 1979 field collections from the same geographic area (Veracruz, Mexico) were $0.971 \pm 0.00$. Average / values between the 


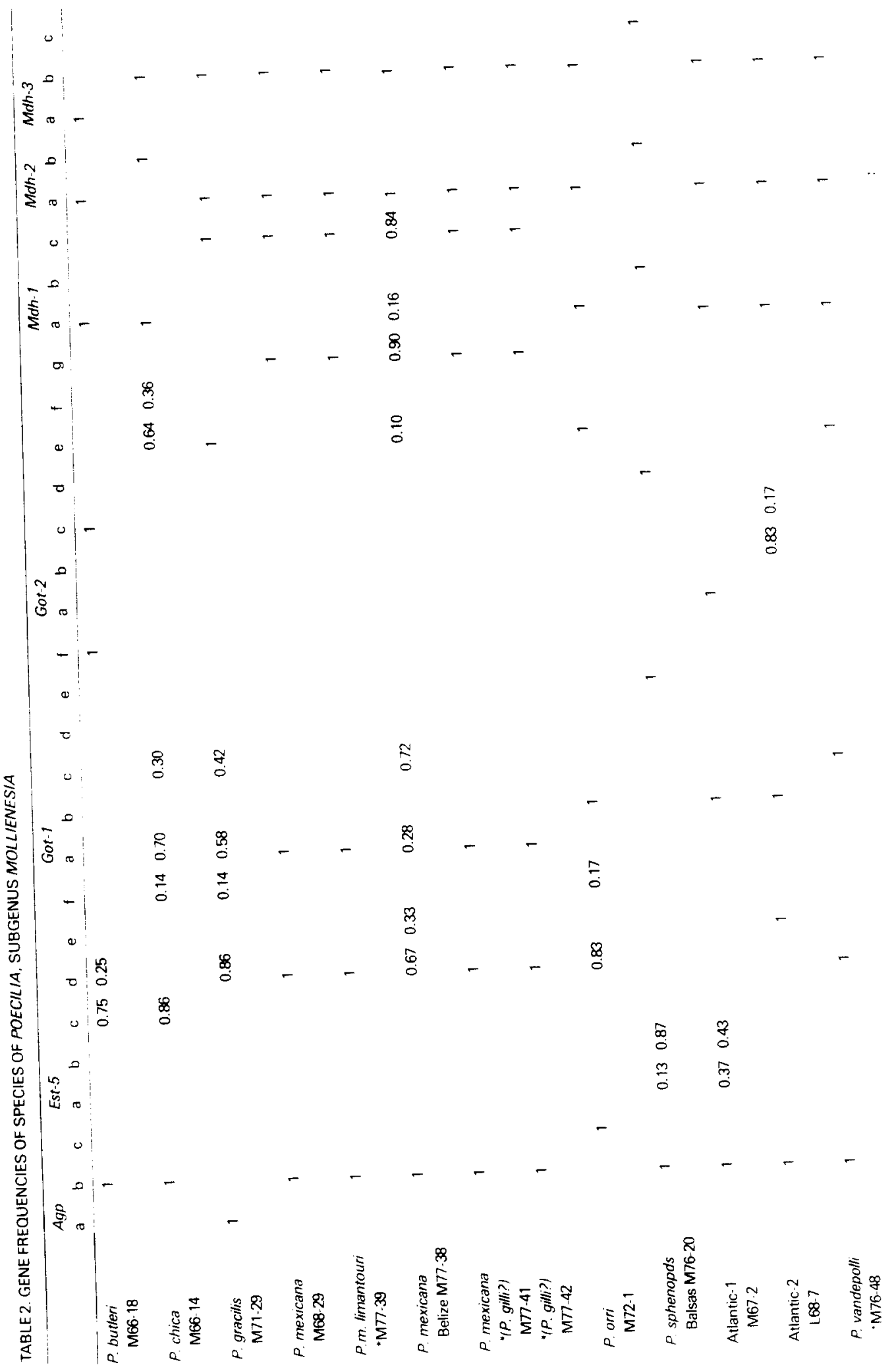




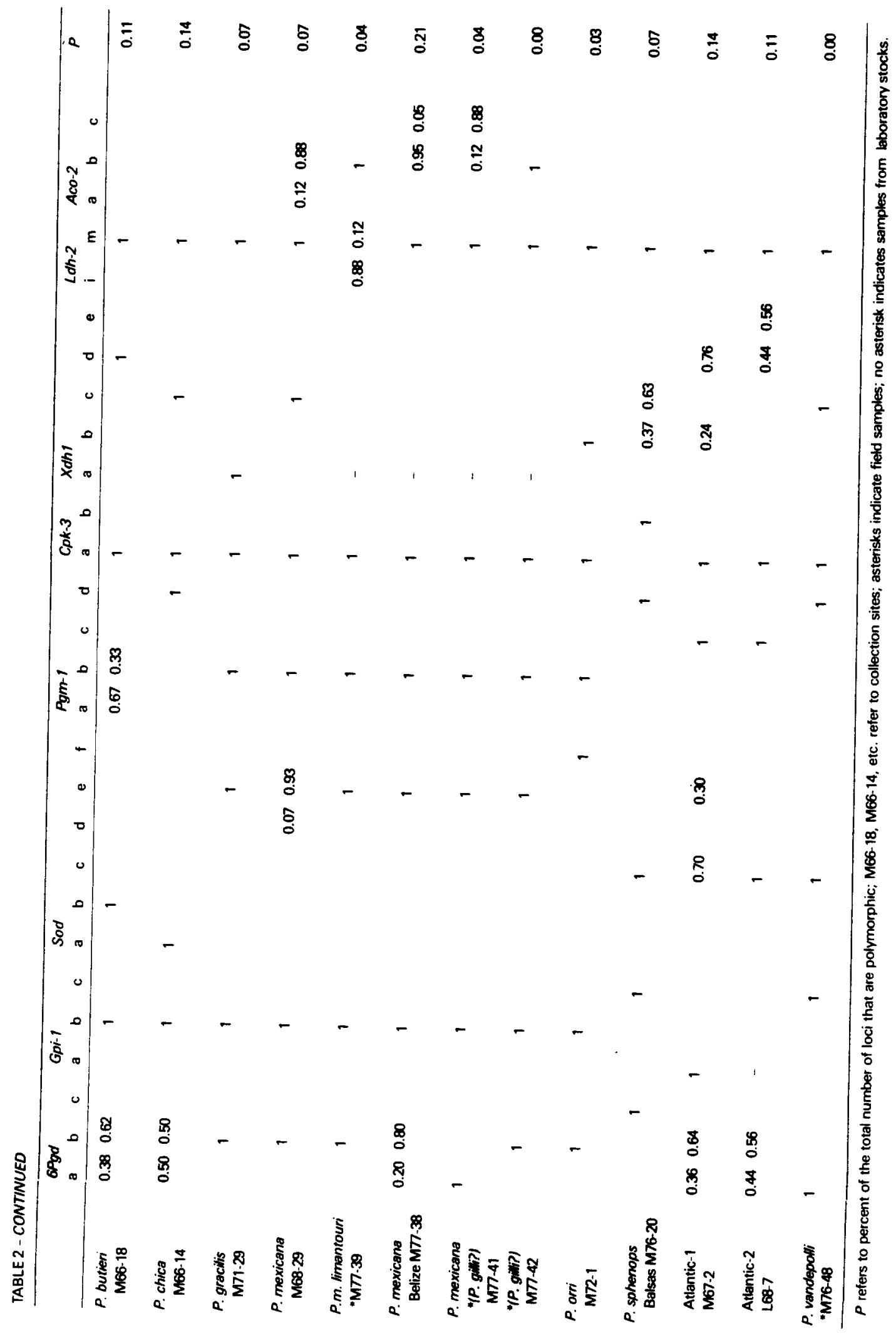




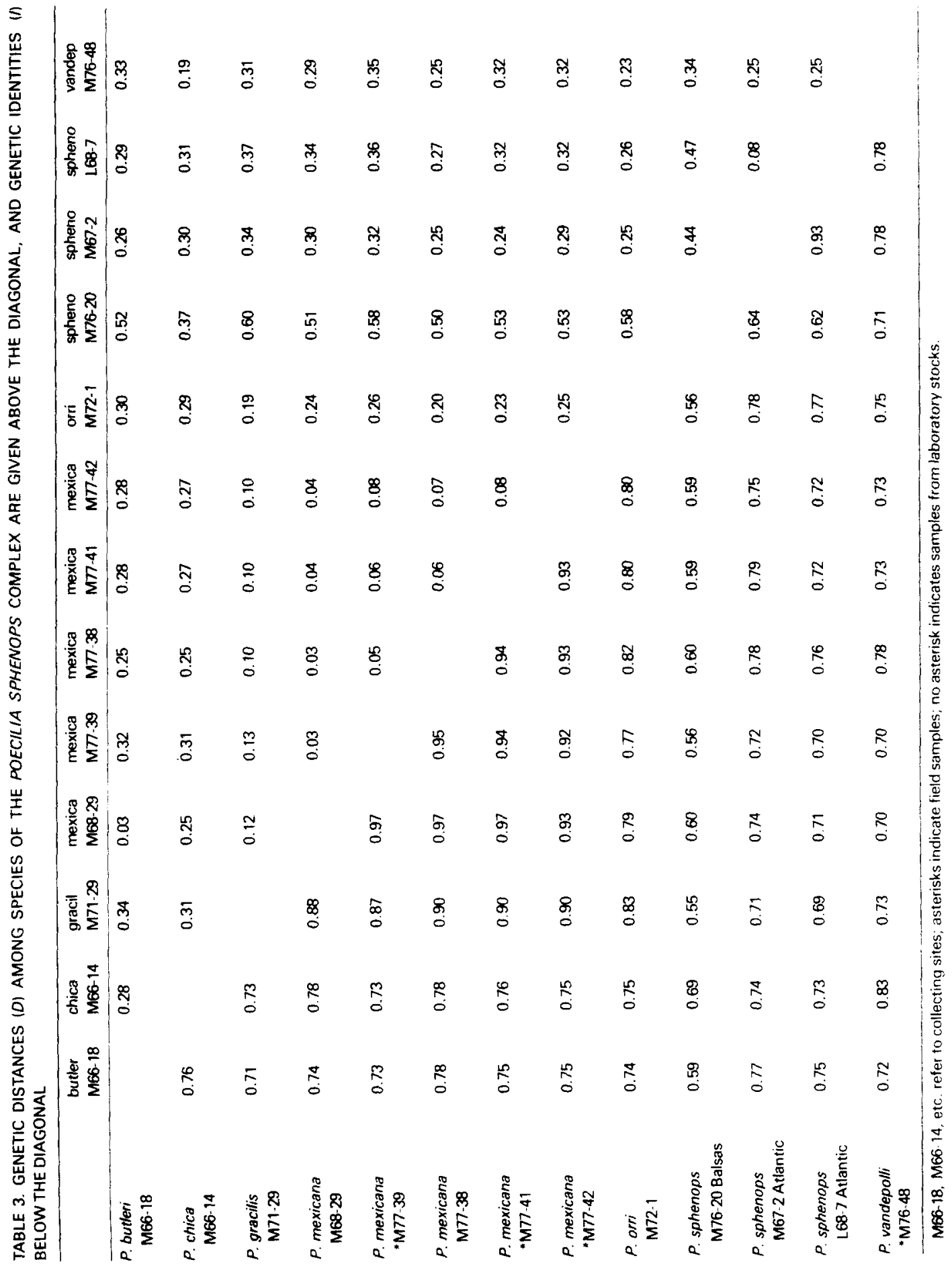




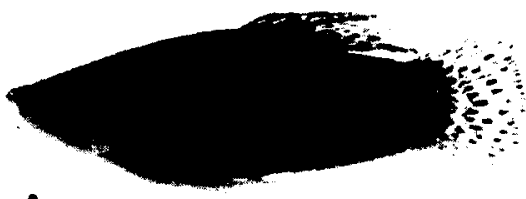

A

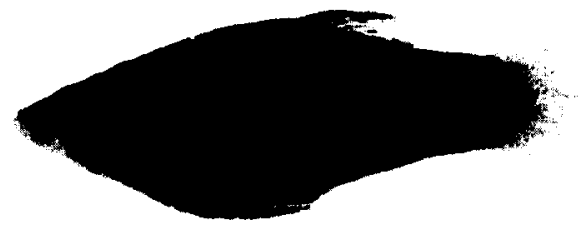

B

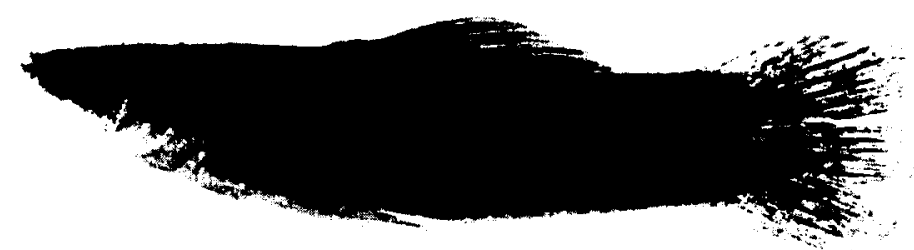

E

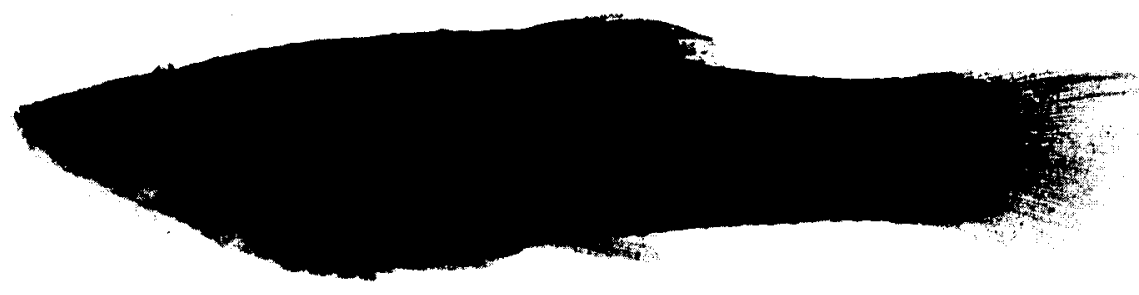

$\mathbf{F}$

FIG. 2. REPRESENTATIVES OF THE POECILIA SPHENOPS COMPLEX ARE FIGURED HERE. Recent photographs of other species in the complex have been figured in ref. $[6]$ (P. mexicana and $P$. sphenops); ref. [18] (P. mexicanal; ref. [8] (P. catamaconis and $P$. chica). (A) Poecilia orri from San Roque Creek, Belize UMMZ 202029, male $36.7 \mathrm{~mm}$, (B) female, $44.6 \mathrm{~mm}$; (C) $P$. vandepolli from Pescadera Bay beach, Curaça UMMZ 19927, 2, male $36.5 \mathrm{~mm}$, (D) female $42.2 \mathrm{~mm}$; (E) P. "gracilis" from Laguna de Petén, Guaternala UMMZ 143710, male $58.0 \mathrm{~mm}$, (F) female, $83.6 \mathrm{~mm}$. Scale bar $=30 \mathrm{~mm}$.
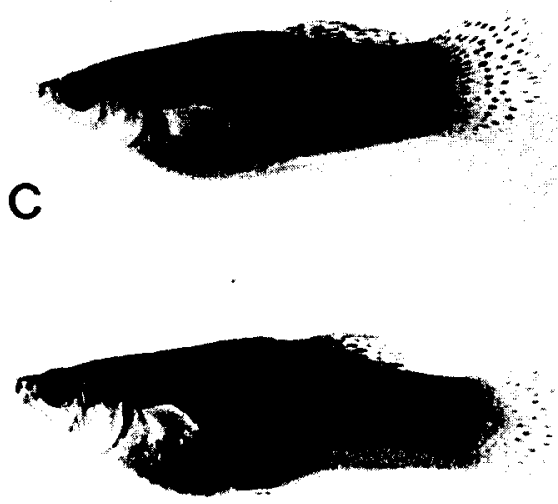

D

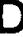



Veracruz $P$. sphenops laboratory stocks (collected in 1967 and 1968) and the 1979 Veracruz field collections were $0.943 \pm 0.02$. Between drainage I values range from 0.96 to 0.98 in $P$. mexicana and 0.95 to 0.98 in $P$. sphenops (22). The average $I$ value between 24 field populations 1500 individuals) of $P$. mexicana and 22 field populations 1365 individuals) of $P$. sphenops was $0.721 \pm 0.01$. The average / value between one laboratory population of $P$. mexicana and two of $P$. sphenops was $0.725 \pm 0.02$.

The morphologically most similar mollies $(P$. mexicana, $P$. sphenops and $P$. butteri are genetically quite distinct (Tables 2 and 3 ). Although there were very few polymorphisms within a presumptive species, the interspecific differences were great. The $P$. sphenops sample from the Balsas drainage on the Pacific coast of Mexico had unique alleles at 10 of the 29 loci examined. $P$. vandepolli (Fig. $2 \mathrm{C}$ and $2 \mathrm{D}$ ) from Curaçao had no polymorphic loci although several alleles showed fixed differences from the other species. $P$. mexicana mexicana and $P$. mexicana limantouri share all alleles. There are frequency differences, however, at $A c 0-1$ and $L d h-2$.

For percentage of polymorphic loci ( $P$ values, see Table 2), 14 of the 29 loci examined vary interspecifically, but within a species, only $0-5$ loci were polymorphic. $P$. mexicana from Belize had the largest number of polymorphisms with 6 of 29 loci polymorphic. The M77-42 stock of $P$. mexicana from Costa Rica and the $P$. vandepolli stock (the only island population analysed) showed no polymorphisms and no unique alleles.

Sod, 6Pgd, Mdh-1, Mdh-2 and Mdh-3 each show unique allelic patterns for many of the species (Table 2). There are marked interspecific differences in the Nei identity and distance values [24], but few differences among populations of the same species (Table 3), except for P. sphenops, which may represent more than one species.

Distributional (Atlantic vs Pacific drainages) or morphological criteria (unicuspid vs tricuspid inner teeth) did not cluster the samples in groups with greater than average similarity (see Table 4, and Fig. 3i.

\section{Discussion}

The widespread mollies of the Poecilia sphenops species complex have posed a taxonomic problem for the past century. Morphologically, all
TABLE 4. MEAN VALUES OF NEI IDENTITY VALUES

\begin{tabular}{|c|c|c|c|c|}
\hline & $\mathbf{x}$ & SD & SE & $\mathbf{N}$ \\
\hline Interepecific all species & 0.725 & 0.080 & 0.015 & 28 \\
\hline Tricuspid species & 0.630 & 0.090 & 0.050 & 3 \\
\hline Unicuspid species & 0.758 & 0.056 & 0.019 & 9 \\
\hline Atlantic coast species & 0.790 & 0.067 & 0.027 & 6 \\
\hline Pacific coast species & 0.675 & 0.085 & 0.050 & 3 \\
\hline \multicolumn{5}{|c|}{ Average of each species with all other species } \\
\hline P. butleri & 0.719 & 0.060 & 0.023 & 7 \\
\hline P. chice & 0.750 & 0.042 & 0.016 & 7 \\
\hline P. gracilis & 0.734 & 0.107 & 0.041 & 7 \\
\hline P. mexicana & 0.751 & 0.000 & 0.034 & 7 \\
\hline P. orri & 0.743 & 0.076 & 0.029 & 7 \\
\hline P. sphenops (Balsas) & 0.617 & 0.053 & 0.020 & 7 \\
\hline P. sphenops (Ati.) & 0.733 & 0.053 & 0.020 & 7 \\
\hline P. vandepollintraspecific & 0.750 & 0.042 & 0.016 & 7 \\
\hline P. mexicana & 0.948 & 0.018 & 0.006 & 10 \\
\hline P. sphenops & 0.730 & 0.173 & 0.100 & 3 \\
\hline $\begin{array}{l}\text { P. sphenops } \\
\text { no Balsas pop. }\end{array}$ & 0.930 & & & 1 \\
\hline
\end{tabular}

Mean (X), Standard Deviation (SD), Standard Error of the Mean (SE), Number of Comparisons (N).

presumptive species strongly resemble one another (Fig. 2). Allozymic information apparently can serve as a tool for interpreting the evolutionary relationships in the $P$. sphenops complex, or at least for distinguishing the species. The results of an allozyme analysis of ten populations of seven presumptive species showed that each presumptive species was defined by relatively nonvariable "diagnostic" alleles (Tables 2 and 3). Although laboratory animals do not provide information on the geographical variation of a species, comparison of our stocks with fieldcaught samples showed that the laboratory stocks provided good approximations to the species as a whole. Such evidence is concordant with the findings of Nei [21] and Gorman and Renzi [25], who showed that if geographical variation is small within a species then allozymic data from small samples can validly represent species for interspecific comparisons. Our allozymic data support the concept of a multispecific complex [8] rather than a single, morphologically variable species. Allozyme data also support the specific status of $P$. orri and $P$. vandepolli (Fig. 1), both of which have been either unrecognized or treated as subspecies of Poecilia sphenops '[1].

One surprising result of our study was the number of divergent alleles detected in the $P$. sphenops population from the Balsas drainage. The Nei identity values between the Balsas 


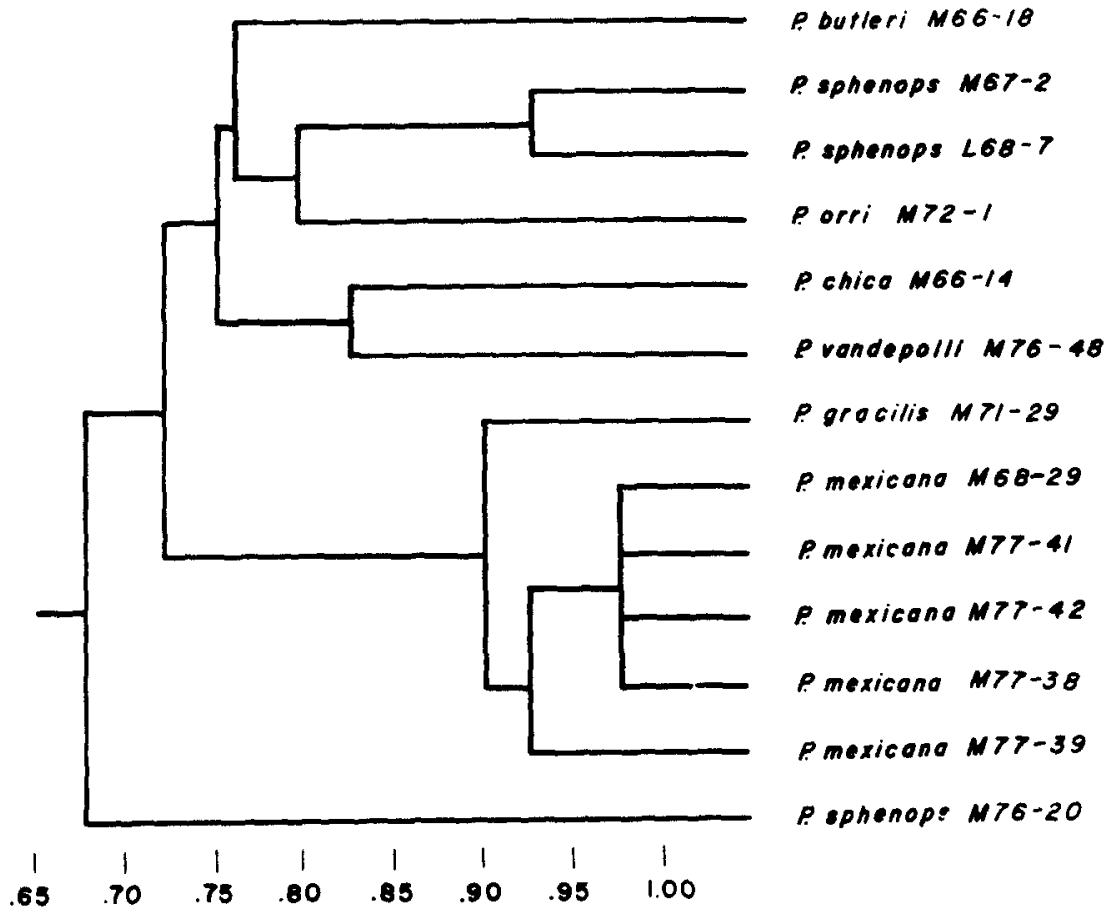

FIG. 3. THIS CLUSTER MAP IS PRESENTED AS A VISUAL REPRESENTATION OF TABLE 3 BASED ON NEI IDENTITY VALUES. No evolutionary relationships are implied. This figure was constructed using SAS hierarchical clustering technique $|43|$.

population and the other populations were unusually low, falling between 0.50 and 0.65 (Tables 3 and 4). Several authors $[6,27]$ have previously suggested that the Rio Balsas populations are morphologically different from other Mexican $P$. sphenops. Our Balsas population is clearly distinct from the other mollies examined. However, we have not yet examined other populations of $P$. sphenops from the Pacific drainages and at present do not know if the distinctiveness of the Río Balsas sample reflects specific level divergence or extreme geographic variation. In addition, morphological data [6] suggest three tricuspid forms on the Pacific slope of Mexico, instead of merely one form.

South of the Mexican border the systematics of the $P$. sphenops complex are still unclear. Faunas disturbed by tectonic activity and stream capture complicate the picture [26]. Allozymic data may eventually clarify this issue.

The allozymic distinctiveness of the members of the $P$. sphenops complex and their interfertility in the laboratory suggest that the complex will be a useful genetic system for mapping large numbers of allozyme loci as has been done with Xiphophorus [28].

Much evidence suggests that genomes are essentially mosaic with respect to their patterns of evolutionary change; in many groups there is almost no correlation among morphological, allozymic, chromosomal or other types of genetic differentiation [29-36]. The shortfin mollies provide yet another example of this phenomenon. Their morphological divergence has been, on the whole, minimal and they are interfertile in the laboratory, but the allozyme data indicate that their evolution has involved marked genetic divergence on at least one level of organization.

\section{Experimental}

Allozyme surveys were conducted on ten populations of seven presumptive species representing field-caught specimens and laboratory stocks maintained at The University of Michigan Museum of Zoology (Table 1). Three stocks of P. sphenops were used; two from the Atlantic siope and one from the Pacific slope of Mexico. P. vandepolli (collection site M76-48, Table 1 contains locality information) from Curaçao, $P$. 
mexicena limantouri [37], and P. mexicans (cf. P. gilfi, MT7-41, $M 77-42)$ were field-collected and maintained alive until tissue extracts were prepared; eight fish were scored for each enzyme (Table 2). Enzyme staining solutions and buffers routinely used in Bruce J. Turner's laboratory for allozyme analyes using starch gel electrophoresis were similar to those in general use [38-42]. Field specimens were frozen on dry ice and held at $-90^{\circ}$ until extracts of tissues could be prepared. Laboratory animals were stored at $-90^{\circ}$ for later dissection or were frozen at $0^{\circ}$ and disesected within $2 \mathrm{~h}$. Extracts for electrophoresis were prepared in advance and stored at $-90^{\circ}$. immediately prior to electrophoresis, they were thawed and centrifuged at 15000-20000 g at $4^{\circ}$ for $20-30 \mathrm{~min}$. Alleles were assigned letters according to their mobility, the slowest alleles being a; a1, 82, etc. were used to designate alleles between $a$ and $b$. Loci were assigned numbers according to their mobility; the slowest anodal locus was designated 1, a more anodal locus would then be 2 .

Acknowledgements - We with to thank Robert R. Miller for helpful comments; the following provided live stocks of mollies used in this study, William E. Bussing, Ingvar Kristensen, Rezneat M. Darnell, Albert Klee, James A. and Martha B. Lackey, Joanne Norton, Russell Norris, Michael L. Smith, Ross Socolof and Don C. Taphorn. This research was supported by NSF grants BMS 72 02378, DEB 7717315 , DEB 7620958 (B.J.T.), DEB 7812025 (B.L.H.B.). Michael Douglas commented on an earlier draft of this manuscript.

\section{References}

1. Rosen, D. E. and Bailey, R. M. (1963) Bull. Am. Mus. Nat. Hist. 128, 1.

2. Zeiske, E. (1968) Z. Vergl. Physiol. 58, 190.

3. Parzefall, J. (1969) Behaviour 33, 1.

4. Parzefall, J. (1970) Z. Morphol. Tiere 62, 211.

5. Parzefall, J. (1974) Z. Tierpsychol. 35, 66.

6. Schultz, R. J. and Miller, R. R. (1971) Copeia 282.

7. Miller, R. R. (1973) Am. Soc. Ich. Herpet. 53rd Annu. Meet. San Jose, Costa Rica, Abstr.

8. Miller, R. R. (1975) Occas. Pap. Mus. Zool. Univ. Mich. $672,1$.

9. Bussing, W. A. (1976) Investigations of the lcthyofauna of Nicaraguen Lakes (Thorson, T. B., ed.), pp. 157-175. School of Life Sciences, University of Nebraska, Lincoin, Nebraska.

10. Denton, T. (1973) Fish Chromosome Methodology. Charles C. Thomas, Springfield, Illinois.

11. Kriebel, R. M. (1980) J. Morphol. 165, 157.

12. Balsano, J. S. and Rasch, E. M. (1974) J. Fish Biol. 6, 51.

13. Balsano, J. S. and Rasch, E. M. (1975) Am. Zool. 15, 830.

14. Kriebel, R. M. (1980) Tissue Res. 207, 135.
15. Parzefall, J. (1973) Genetics and Mutagenesis of Fish (Schroder, J. H., ed.), pp. 177-183. Springer, Berın.

16. Parzetall, J. (1979) Z. Tierpsychol. 60, 399.

17. Peters, N., Peters, G., Parzefall, J. and Wilkens, H. (1973) Int. Rev. Ges. Hydrobiol. 68, 417.

18. Tumer, B. J., Brett, B. L. H. and Miller, R. R. (1980) Evolution 34, 917.

19. Tumer, B. J., Brett, B. L. H., Rasch, E. M. and Balsano, J. S. Evolution 34, 246.

20. Vrijenhoek, R. C. and Allendorf, F. W. (1980) /sozyme Bull. 13, 92.

21. Noi, M. (1978) Genetics 89, 583.

22. Brett, B. L. H. (1981) Ph.D. Thesis, The University of Michigan, Ann Arbor, MI.

23. Simenek, D. E. (1978) Nature 276, 612.

24. Nei, M. (1972) Am. Nat. 106, 283.

25. Gorman, G. C. and Renzi, J. Jr. (1979) Copeia 242.

26. Rosen, D. E. (1979) Bull. Am. Mus. Nat. Hist. 162, 267.

27. Buen, F. de (1943) An. Inst. Biol. Mexico 14, 251.

28. Morizot, D C., Wright, D. A. and Sciciliano, M. J. (1977) Genetics 83, 645.

29. Brown, W. M., George, M., Jr. and Wilson, A. C. (1979) Proc. Natt. Acad. Sci. U.S.A. 78, 1967.

30. Carson, H. L. (1978) Ecological Genetics (Brussard, P. F., ed. I, pp. 93-107. Springer, New York.

31. Carson, H. L. and Bryant, P. J. (1979) Proc. Natt. Acad. Sci. U.S.A. $78,1929$.

32. Turner, B. J. (1974) Evolution 28, 281.

33. Turner, R. G., Johnson, M. S. and Eanes, W. F. (1979) Proc. Natl. Acad. Sci. U.S.A. 76, 1924.

34. Wilson, A. C., Bush, G. L., Case, S. M. and King, M. C. (1975) Proc. Nat. Acad. Sci. U.S. A. 72, 5061.

35. Wilson, A. C., Maxson, L. R. and Sarich, V. M. (1974) Proc. Natt. Acad. Sci. U.S.A. 71, 2843.

36. Wilson, A. C., Sarich, V. M. and Maxson, L. R. (1974) Proc. Natt. Acad. Sci. U.S.A. 71, 3028.

37. Menzel, B. W. and Darnell, R. M. (1973) Copeiz 225.

38. Harris, H. and Hopkins, D. A. (1976) Handbook of Human Genetics. Elsevier/North Holland, New York.

39. Siciliano, M. J, and Shaw, C. R. (1976) Chromatographic and Electrophoretic Techniques (Smith, I., ed.), 4th edn, Vol. 2, pp. 185-209. W. Heinemann Medical Books, London.

40. Selander, R. K., Smith, M. H., Yang, S. Y., Johnson, W. E. and Gentry, J. B. (1971) Stud. Genet. 6, Univ. Texas. Publ. 7103, 49.

41. Shaklee, J. B., Christiansen, J. A., Sidell, B. D., Prosser, C. L. and Whitt, G. S. (1977) J. Exp. Zool. 201, 1.

42. Shaw, C. R. and Prassad, R. (1970) Biochem. Genet. 4, 297.

43. Johsen, S. C. (1979) SAS Users Guide (Helwig, J. T. and Council, K. A., eds.), pp. 15-161. SAS Institute, Carey, NC. 